\title{
Healing as transformation and restoration: A ritual-liturgical exploration
}

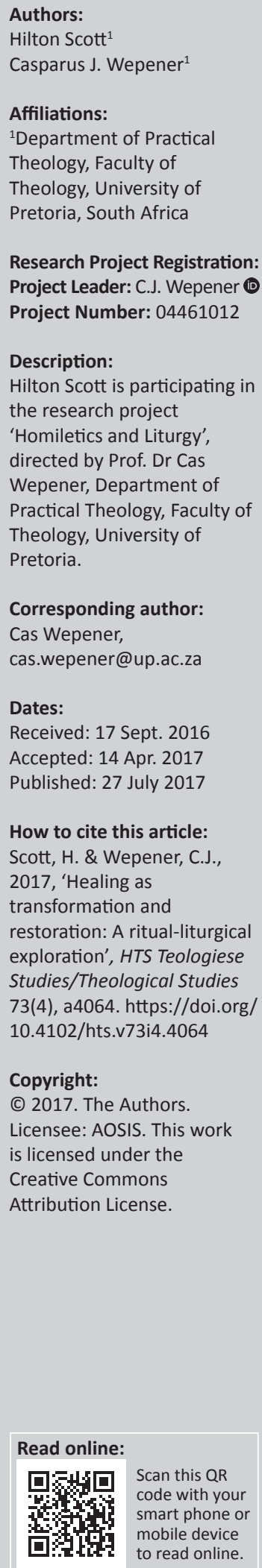

Illness is a reality that affects all people, and healing is the main reason why people attend worship services in sub-Saharan Africa. According to the Ritual Studies scholar Ronald Grimes, illness is a social reality; it is socially imagined and constructed. Healing in the church is something that many believers experience, also in the context of worship and liturgy. In order to explore such healing as it occurs in liturgy a research project was undertaken making use of both empirical work and a literature study. The aim of this research was to take the light off of direct pastoral care and investigate how the liturgy affects individuals within the congregation with regard to healing. A praxis-theory cycle was followed in the research, and a preliminary liturgical theory for praxis was developed based on the insight from the empirical study and ritual theory that healing through worship entails either transformation or reconciliation.

\section{Introduction and background}

Illness is something that affects most people. According to Grimes (2000:342), illness is a social reality; it is socially imagined and constructed - it is how we imagine sickness. Illness can be emotional, in the sense that traumatic and emotionally painful experiences require healing. Healing is an integral part of many believers' relationship with God in the modern Church, whether physical or emotional (cf. Scott 2013:3). As a result pastoral care has become a very important facet when describing the roles of a minister within the congregation. Added to this, healing is one of the main reasons why people in sub-Saharan Africa attend worship services, and healing has also been described as one of the 'languages' of worship in Africa (cf. Wepener 2014; 2015a).

In this article the authors report on a research project that was recently executed in Pretoria, South Africa (cf. Scott 2013). The aim of this research was to take the light off of direct pastoral care and investigate how the liturgy affects individuals within the congregation with the proverbial magnifying glass focusing on the use of the liturgy as an invitation into healing, specifically emotional healing. In order to discover the role of such healing, qualitative research in a local Methodist congregation in Pretoria was included in the overarching research design to augment the literature study.

The topic of healing in the church is one of polar opinions with regard to its efficacy - a simple Google search on 'Christian Healing' brings up many different responses to healing; both good and bad in terms of people's opinions and experiences, especially when it comes to physical healing. Physical healing in the church is a very controversial topic and is one that people have very strong opinions about. 'Healing' involves physical healing; however, the focus in this article, without excluding physical healing, is more on emotional healing. As Ronald Grimes (2000:342; cf. also Wepener \& Müller 2013) states: 'to be cured is to be fixed, to be healed is to be reconnected'.

Emotional healing is the healing of one's psychological wounds caused by traumatic experiences that have, in one way or another, altered the person's life in a negative way (cf. Scott 2013:2). In general this would mean the purging of the experience so that the person could move forward from the experience and no longer let the experience affect the person's life in the way they think, the way they react to temperamental situations and the way they carry out their lives. Due to the fact that the focus of the study is on worship and liturgy, a ritual-liturgical approach was utilised in order to do the investigation. In this regard the methodology and especially ritual theory, will be discussed in the next section.

\section{Methodology and theory}

The researchers adopted the principles developed by Osmer, which he calls the core tasks of practical theological interpretation' (Osmer 2008:4), and used them in parallel with the principles

Note: This article represents a reworked version of aspects from the MA dissertation of Hilton Scott, titled, 'Healing and transformation through the worship service: A ritual -liturgical exploration', completed under the supervision of Prof. Dr Cas Wepener in the Department of Practical Theology, Faculty of Theology, University of Pretoria. 
of participation action research (PAR) (cf. Strydom 2002) also as applied to liturgical studies (cf. Wepener 2005, 2010). The so-called core practical theological tasks will be listed as titled by Osmer and each task will be described, as it has been adapted by the researchers for the research. Within this overarching design theory coming from ritual studies and also liturgical studies was utilised.

This first descriptive-empirical task involves gathering information that helps discern patterns and dynamics, in particular episodes, situations or contexts (Osmer 2008:4), thus asking the question: 'What is going on?' with regard to the theme of healing through liturgy. Here, the researchers used qualitative research methods to collect the necessary data. These methods were (1) one-on-one, semi-structured interviews (Thumma 1998:205-206), where members of the congregation could refer themselves to the researcher doing the field work for interviewing if they felt they had an experience to share pertaining to the main research theme. Besides the interviews (2) 'thick descriptions' (cf. Geertz 1973:3-30) of worship services at the church were also collected: observations of worship services and the liturgy, as well as the congregation's reactions to both, were made. This task and the research processes explained in it have been performed in a way that the method of PAR is being used, where the traditionally uninvolved researcher is participating in the whole research process and the traditionally silent respondents are being given a voice, along with the researcher, as co-researchers. This means that there is collaboration between subject and object in the research process (Wepener 2005:115).

Once it was clear what was going on at the church, the researcher asked the second question: 'Why is this going on?' (Osmer 2008:4). This question involved looking to the arts and science, in order to interpret different episodes, situations and contexts. When interpreting research data it is important to know which theories from the arts and sciences the researcher will use. During the processes of interpretation the researcher needed to use his 'tamed intuition' (Lukken 1997:145) to know when distance or proximity to the subject was relevant:

A researcher needs close proximity to the subject matter studied to have access to the finer nuances. However, a certain amount of distance can also help a researcher to gain a certain amount of perspective of the activities under observation. (Wepener \& Barnard 2010:203)

The third question involved looking at various norms to find out 'What ought to be going on?' (cf. Osmer 2008:4). The researchers needed to take note of what was happening and compare it with what should be happening whilst discerning between the relevant factors. This was performed whilst always keeping the final goal of liturgical inculturation in mind. The reason being that the final task involved creating a new theory for praxis, which needed to be performed in a liturgically inculturated way. This involves finding a balance between the liturgical traditions of the church, what the congregation wants and needs, Biblical norms, as well as the cultures in which the specific liturgy is celebrated. This can be illustrated by Chupungco's example (1992:32): 'The process itself may be pictured as lighting a candle at both ends. The idea is to make both ends meet in a literal, not idiomatic, sense'. It is important to realise that the researcher did not only use theological concepts but also concepts from ritual studies, for example, and this means the whole approach of this research can be termed as liturgical-ritual studies (cf. Barnard, Cilliers \& Wepener 2014).

The final or pragmatic task 'consists of determining strategies of action that will influence situations in ways that are desirable and entering into a reflective conversation' (Osmer 2008:4). In other words, here the researchers considered the results of the research and interpreted them using the normative to develop a strategy that may be used by the church in order to develop an inculturated liturgy with regard to the theme of healing.

It is important to realise that to invent brand new liturgical rituals for any denomination or congregation would be less than ideal as 'life is not possible if we have to totally re-invent anew every time the ways in which we act and engage with each other and the Other' (Wepener 2008:313). However, to re-invent rituals or rites of passage or liturgy is acceptable (often necessary) as long as it keeps to the tradition of that Church, in agreement with the following statement by Muchimba (2007):

I am very strongly convinced that if an indigenous group had only a Bible, they would practice their worship in a manner that would be relevant to their culture and within a biblical framework. (p. 6)

Taking this into account, one can see that the inclusion of culture in liturgy is important and necessary to deliberately work towards an ongoing process of liturgical inculturation. To explain this is Chupungco's (1992:29) straightforward example of liturgical inculturation: $\mathrm{A}$ (liturgy) $+\mathrm{B}$ (culture) $=$ $\mathrm{C}$ (a new entity or inculturated liturgy) and not $\mathrm{A}+\mathrm{B}=\mathrm{AB}$. In other words, through the process of liturgical inculturation something new comes into being. This is also the main aim of this article, namely to serve an on-going process of liturgical inculturation specifically with regard to the theme of healing in and through the worship service which is a critical theme in our own day, especially in subSaharan Africa (cf. also Post 2014).

\section{The descriptive-empirical task Interview methodology}

The interviews for the qualitative empirical part of the study were set up with the intention of being 'semi-open', thus avoiding any excessively rigid structure in accordance with PAR's qualitative nature (Babbie \& Mouton 2001:326). There were four predetermined questions that were asked in order to guide the co-researchers to stay with the theme of the research project whilst still allowing them to speak freely and share their experience. The questions were used as a broad boundary to keep the co-researchers from straying away 
from the experience(s) in question (cf. in this regard also Root 2014:ch 3). These interviews were conducted over a 3-month period. The questions were as follows:

1. Do you believe that healing is possible through worship?

2. Do you have a personal experience of healing in worship that you would like to share?

3. Do you feel that this experience that you have described changed you? If so, how?

4. In your opinion, how could the liturgy better serve the needs of worshippers to experience healing through worship?

The interviews were later transcribed as thoroughly and as 'verbatim' as possible. A total of 8 interviews were conducted, with a total of 10 co-researchers: 6 individual interviews and 2 interviews each involving a couple. It was clear from the last interviews that data saturation was achieved (cf. Scott 2013:20-45, 105-163). It was requested that any person who volunteers for an interview be above the age of 18 ; therefore, all the interviewees ${ }^{1}$ were adult members of the congregation who volunteered and were interviewed at their own consent. Thumma suggests that these interviewees should be representative of the congregation, and therefore the interviewees were from different walks of life, some of them were newer to the church than others, some had grown up at the church and are now retired, and they ranged from being complete insiders - aware of the more intricate details of the church - and newer members who had a more perceptive opinion of what goes on at this Church as well as good representativity with regard to age and gender (cf. Thumma 1998:205).

\section{Healing as transformation and restoration through worship: Core themes from the qualitative empirical research}

The following section is a summary and illustration of the two most common themes that were found in the interviews. A process of inductive coding was used in order to identify the core themes recurring in these interviews. In this regard, the work of Pieterse (2010; 2012; 2013a; 2013b) in homiletics and Wepener (2013; cf. also Wepener \& Pieterse 2016) in liturgical studies guided the process. From the longer list of themes two main themes that emanated from the coding were chosen as the main themes. None of the experiences of healing as reported upon by the co-researchers were the same, although core themes emerged from the transcribed interviews. The two main codes that surfaced and that will be elaborated upon here are firstly transformation and secondly restoration and reconciliation.

\section{Transformation}

Transformation was the most prominent theme or code that came from the various interviews. There is a definite correlation between the importance of transformation to this study and specifically in the interviews. The reason probably being that transformation is one of the three key ideas that defines a rite of passage as opposed to a ritual (Grimes 2000:6) and that aspects of rites of passage can also be traced back to most liturgies.

By studying the transcriptions it is possible to see that five interviews show evidence of transformation. In two of the interviews, transformation is achieved through reconciliation the restoring of a relationship. Again this theme is an aspect that needs to be investigated further in both the interpretive task and normative task within this practical theological inquiry. What is significant at this stage is the fact that the co-researchers themselves mentioned transformation as the first and main way on how they experience healing in the worship service; the second main theme can be described in making use of two related concepts, with restoration and reconciliation, which are both also related to transformation.

\section{Restoration and reconciliation}

A second important theme that emerged from the data collected is that of reconciliation or restoration. Firstly, the reason for grouping restoration and reconciliation together is because that is how the co-researchers spoke about it and secondly because a definition of reconciliation can involve restoration. Wepener (2009:49) defines reconciliation as the continuous process through truth and justice aimed at the restoration of broken relationships, so that a new reality which is qualitatively different to any previous relationships comes into being', which is a definition that was influenced by the work of John de Gruchy (2001), specifically the book Reconciliation. Restoring Justice. Reconciliation and restoration are two separate topics; however, the one works off of the other and therefore they should be kept together in order to avoid redundancies whilst explaining either of them. As seen above, transformation can also work hand-in-hand with reconciliation.

Only these two themes will be discussed in this article as they were the most prominent themes. The other important themes that emerged from the coding of the transcribed interviews were physical healing, prayer, lament, and 'diasporic healing'2 (cf. Scott 2013:41-45). This empirical work was necessary in order to arrive at this point, namely to know that when worshippers refer to healing through the liturgy, the main and most prominent understanding of healing relates to transformation as well as restoration and reconciliation in the first instance and secondly also the above themes. Within a practical-theological hermeneutical praxis cycle, this is a very important point of departure in order to guide the rest of the study towards liturgical inculturation.

\section{The interpretive task, using the arts, sciences and the empirical data}

According to Osmer (2008:83), theoretical interpretation 'is the ability to draw on theories of the arts and sciences to understand and respond to particular episodes, situations, or

2.A term coined for people that leave a particular congregation if they do not find the healing they long for there and then to seek that healing elsewhere. 
contexts'. The two identified themes will now be enriched by making use of mainly ritual theory of Grimes (cf. 2000; 2010) and Bell (cf. 1997) as well as the work of several liturgists.

\section{Transformation}

When it comes to rituals and especially rites of passage, transformation is fundamentally important (cf. Van Gennep 1960; Turner 1969). When deciding on the questions for the interviews, question three was specifically constructed in a way that it would openly question the possibility of transformation without directly putting the idea in the heads of the interviewees, in other words leading the question. It has already been determined that, with regard to rites of passage, transformation is a metamorphosis after which a person is 'moved' from one social position to another, for example a girl becoming a woman.

When the theme of transformation surfaced, as a result of the interview questions, one of the interviewees responded with enthusiasm saying: 'Ja, I'm totally transformed, totally' and then goes on to explain how. After the interviewee gave plenty of evidence to support the apparent transformation, she ended the response to question three by saying the following: 'So it's been progressive, changes like that'.

A description of rites of passage can be given as follows: rites of passage are the transportation of a person from one state of being to another. Effectively, a rite of passage will carry one from one state or place from which they are unable to return. Rites of passage depend on a 'momentous metamorphosis', not a moment where one gets emotionally carried away and thereafter returning to their original condition. Rites of passage hinge on transformation and are developed with this in mind. Transformation can be explained as that moment in which a caterpillar becomes a butterfly, a moment after which one is never again the same. Rites of passage differ to the larger overarching category of rituals, as ritual practices such as weekly worship are responses to recurring needs. Such rites move people; however, rites of passage are explicitly aimed at transforming individuals and alter their identity and social positioning. Both rituals and rites of passage, when enacted, involve performance, but only rites of passage are explicitly aimed at transformation (cf. Bell 1997; Grimes 2000; Scott 2013:50).

A rite of passage is a one-off experience for those undergoing the rite; ${ }^{3}$ ritual practices can be repeated regularly, weekly worship being the simple example. This begs the question 'is it change, or movement, or is it transformation?' Firstly, a synonym of transformation is change but then again so is metamorphosis. In the working definition given above it states that transformation in rites of passage involves metamorphosis; however, different from metamorphosis this is on-going transformation and can occur more than once and even repeatedly. The co-researchers experienced the transformation as a journey of change and not just a single, momentous 3.Exceptions are, of course, marriage after death and divorce. metamorphosis, and they experienced transformation in the sense of an open and on-going process.

Taking the number of times the word 'restoration' and its related forms were mentioned and taking the presupposition that this is a recurring need, it can then be deduced that the transformation that was experienced by the co-researchers was a metamorphosis but not a metamorphosis that can be attributed to transformation. This metamorphosis is a slower process and is not momentous, thus making it a slower process as a result of continual ritual practice in the form of weekly worship.

The transformation mentioned in the example above cannot be seen as resembling the change as it occurs through rites of passage, because it is not fitting either Grimes' distinction of what a rite of passage is or matching up with the above description of rites of passage. Thus another type of rite needs to be explored in order to better understand what is meant in this regard, namely rites of exchange. Rites of exchange are usually religious rituals that involve humans giving something, sometimes tangible, with the expectation of receiving something in return; this swap - or exchange - is between human and divine power or deity (Bell 1997:108). When saying 'giving something', which is quite a broad term, what is meant is that a person can give, as an example, an offering of food or money; it depends on the religion and its doctrine.

From a Christian perspective, one could say that going to church on a Sunday morning for weekly worship, praying and recommitting oneself to the Lord, could among other things also be seen as an offering. ${ }^{4}$ It is human nature to think 'What do I get out of it?' It wouldn't be unbelievable for one to consider this offering that has been given and consider what might be given in return. Worshippers remind themselves of the sacrifice they have made by singing such lyrics, by Hillsong United, as:
Lord, I offer my life to you
Everything I've been through
Use it for your glory
Lord, I offer my days to you
Lifting my praise to you
As a pleasing sacrifice.
(see http://lyrics-hots.blogspot.com/2013/06/i-offer-my-life- lyrics-hillsong.html)

At the risk of misinterpreting the artist's intentions, it can be noticed through the lenses of rites of exchange that a worshipper may see worshipping, or praising, as an act of offering oneself in and through worship to God. It is preferred to stick with the view of this transformation being related to a rite of passage because of an undoable metamorphosis occurring, although in the light of critical thinking and

4.Romans 12.1 (NIV) says: "Therefore, lurge you, brothers and sisters, in view of God's mercy, to offer your bodies as a living sacrifice, holy and pleasing to God - this is which is found in the worship services of many traditions also suggests this meaning. 
hermeneutics one needs to consider the option of rites of exchange, especially as a result of weekly worship being seen as a ritual practice that responds to a recurring need. Bell (1997) explains these rites as follows:

Rites of exchange and communion help articulate complex systems of relationships among human beings, gods, demons, ancestors, and animals. Such rites call attention to an order in these relationships that all depend upon for their well-being. Offerings to ancestors, gifts from the spirits, or sacrifice in which the object and the god become one all create a profound sense of cosmic interrelatedness and of human responsibility for more than one's own immediate needs. (p. 136)

Another form of transformation is accomplished via a socalled conversion experience. In the Methodist tradition, a conversion experience is an experience where a person gives their life to God and is converted. It could also be, as seen in one interview, where the person is already a church-going person but realises that he or she is attending 'because that is what your parents told you to do and it was the "right" thing to do' and thus experiencing 'the need to move to a deeper level of commitment ${ }^{\prime}{ }^{5}$ It is thus a move from participation in ritual as routine or convention to participation motivated by a particular experience and a new kind of commitment.

This conversion experience may otherwise be explained with reference to Romans 12:2 (NIV): 'Do not conform to the pattern of this world, but be transformed by the renewing of your mind'. Some see this transformation as being reborn as a new person in Christ; in some churches this is ritualised by baptism or liturgical rituals such as the so-called altar call, and in other churches it is simply a realisation. The main point is that two of the co-researchers claimed they were transformed by the renewing of their minds.

An example of metamorphosis and transformation was noticed in the interview with a co-researcher who is a recovering alcoholic, a term used by attendants of Alcoholics Anonymous. This particular recovering alcoholic has, as of December 2012, gone 'nine years and one month and one day' without consuming alcohol of any form. When asked about the possibility of change and an explanation of any change, in question three, he answered as follows: 'immensely, immensely ... It changed my complete being for the better ... I'm not that self-centered bastard that I was, anymore. So, it changed my life completely'. When asked if he had ever relapsed, the following response was given:

... Once, that was during communion in a previous church where they served wine and grape juice and I thought: 'you know what, you're a month clean you can take a sip of wine' and it was the worst day of my life; I craved for alcohol the whole next two days. And from there on I took the grape juice and that was the last time I have ever had alcohol. (Scott 2013:56, 144)

This account indicates that a transformation occurred, a metamorphosis of the mind and will power - moving from someone that would take a chance with revisiting the idea of book and the notion of Christopraxis as Christ ministering and the respondents experiencing it as such. drinking alcohol at all to being someone that realised a weakness and because of it had a transformation of thought from a caterpillar that would chance his or her sobriety to being a butterfly that will try not to take that risk again.

The final situation of transformation is in another coresearcher's experience that occurred in 1979 at the church. The co-researcher clearly recalls the situation and related episode very vividly, remembering very fine details. The most noticeable aspect of the whole testimony is the recollection of the moment that healing took place. A brief revision of this particular episode of healing: the interviewee went to church in early January in 1979 and whilst singing Hymn 371 out of the Methodist Hymn Book, particularly verse four, where the interviewee 'began to feel something working within me, changing me completely ... That was my healing, when I sang that fourth verse in that particular hymn ...'

The importance behind this particular episode is the time in which transformation happened. The definition that was brought out of Grimes' (2000:6-7) book was that transformation requires a 'momentous metamorphosis'. A case can be made that the minuscule time frame has a massive effect on the transformation being momentous, 'a new person in Christ' was created in the time it took to sing a few lines of a hymn. Another perspective to consider through the lenses of Ritual Studies, similar to transformation, is reconciliation. Whether transformation or reconciliation, they are both elements of rituals that may result in healing.

\section{Reconciliation}

Restoration plays an integral role in reconciliation. One of the main reasons the topic of reconciliation was discovered was because of the fact that, during one of the interviews, the interviewer noticed the repeated mention of the word 'restores' or 'restored' by the co-researchers which was also confirmed in the coding process (cf. Pieterse 2010; 2012; 2013a; 2013b). The word 'restores' and its related forms were mentioned 20 times during this and other interviews. Restoration is key to the healing story, or stories, told in this interview and in others and restoration, as was already mentioned, is also closely related to the concept reconciliation.

It is unnecessary to interpret each incident where 'restores' or 'restored' or 'restoring' is mentioned. Instead, the theme of restoration and reconciliation in general will be interpreted. Restoration can be seen as the return of something to a former, or original, condition; synonyms for the word include 'renovation', 'reconstruction' and 'renewal' (cf. Scott 2013:58). A couple that were interviewed together mentioned restoration in a few different domains referring to occupations or vocations; marriage; relationships with family and friends; emotions; and just in general - like 'it restores your soul', as an example.

Another theory is that reconciliation is a process, a journey that takes place between the 'already' and the 'not yet' 
(Wepener 2009:48). This is very different from transformation, which occurs in a much shorter span of time when considering rites of passage or rituals. There are also studies that show how rituals support larger transformation processes on a societal level of which the work of Turner regarding the Social Drama is best known. ${ }^{6}$

The first step of interpretation would be to qualitatively explore the evidence of restoration. With this in mind, one can identify that there is a definite change, or 'renovation', that has occurred with the mentioned couple. Both persons have been through testing times and took the option of leaning on the church, each other and God. The one interviewee mentions God's 'power and His love and His grace'; many Christians believe to have a relationship with God - mainly developed through prayer and worship. Prayer requires talking to the Lord, through Jesus Christ. Another such relationship would be the marital relationship between the couple. The one co-researcher, for example, went through a divorce and came out the other side not wanting another marriage. He experienced reconciliation through restoration in a marital relationship, albeit with a second wife. In this case the conceptual relationship between the co-researcher and a given marital partner was restored; the broken idea of marriage was repaired.

Another qualitative example of restoration is from an emotional point of view. Both co-researchers experienced emotional strife; the one has bipolar disorder which by all accounts has been restored to a controlled and manageable state. On the other hand, the co-researcher experienced feelings of depression whilst going through a divorce, since which time the interviewee has been restored to an 'undepressed' state.

When looking at what aspect of rituals is occurring and aiding in the process of reconciliation, one might immediately turn and point at ritual practices and their purpose to fulfil recurring needs by means of, for example, weekly worship. Looking at reconciliation from a ritual perspective, in other words looking at reconciliation rituals and the various typologies involved, Wepener (2012b:298) categorises 'Therapeutic or Healing' as a type of reconciliation ritual. Other categories that fall under the same heading are: 'Acceptance or Forgiveness', 'Confession' and 'Reparation'.

From a perspective that takes emotions into account, all of the above-mentioned categories can be seen as variations on the theme of healing. When it comes to emotions of forgiveness, as an example, it can be seen as a type of healing or a stepping stone towards healing. The same can be said for confession. Lukken (1999) in this regard speaks of the therapeutic function of ritual. Furthermore, acceptance, forgiveness and confession all depend on relationships; as an example, one cannot confess unless to a third party. Confession, forgiveness and acceptance cannot be performed without a third party and the relationship with said third party. Without a third party to participate and witness one cannot journey towards reconciliation that includes restoration. The co-researchers' experiences fit into the categories of Therapeutic or Healing and Acceptance or Forgiveness. These co-researchers can be said to have been healed through continuous reconciliation ritual practices.

Another mention of restoration in the interviews was made by a co-researcher who said 'His home life was restored, his marriage was saved from this ... he was a completely changed person - a new person in Christ ...'. This account of restoration is a result of a conversion experience. The topic of conversion experiences has already been covered under the previous section of transformation but because of the mention of restoration it is necessary to interpret these episodes through the lenses of reconciliation rituals. A conversion experience is not a repetitive ritual (cf. Lukken 1999:47-55), it is a one-off experience through which a person is transformed and has an irreversibly changed mindset and belief system. A conversion experience is not something that is a recurring need which needs to be satisfied week in and week out. Instead the effects of said conversion experience lead to one having recurring needs and therefore participating in weekly worship in response to said needs.

In the case of one co-researcher, the suicide of a son (a broken relationship) led to a new reality through a conversion experience (truth and justice), resulting in the restoration of another relationship (reconciliation with God):

When talking reconciliation in the Christian sense, it is important to note that grace always takes precedence in the process. People are moved towards reconciliation from God's call to the freedom and joy of reconciliation. (Wepener 2009:48)

This extract above shows that reconciliation, in the Christian sense, and the interviewee's story is the restoration of a relationship between person and God as a response by said person to God's call and by God's grace. Although one only needs to experience a single conversion, reconciliation is still a recurring need, and the necessary rituals involving forgiveness and confession serve as examples.

Therefore it can be said that the conversion experience as experienced by co-researchers in a Methodist worship setting is comparable to a rite of passage, transforming a nonChristian into a Christian. Thereafter the participant of the conversion experience will then, repetitively, participate in ritual practices that involve reconciliation in order to keep restoring the relationship that has been formed through the grace of God. Bell (1997:47) quotes Robertson Smith stating that religion is the relation of 'all the members of a community to a power that has the good of the community at heart'. In addition to this Bell (1997:48) says that 'religious rituals are concerned with common traditions of communion with spirits, ancestors, or gods and tend to address emotional and psychological needs'. There are various ways in which this relationship can be continuously restored; one such way is through the liturgical ritual of prayer. Prayer can be 
performed in the church service as well as out of it, and it can be performed as a public practice or in private.

\section{The normative task}

This part of the research process entails the use of theological concepts to interpret particular episodes, situations or contexts, constructing ethical norms to guide the responses and learning from 'good practice' (Osmer 2008:4). The researchers had to take note of what was happening and compare it with what 'should be happening' whilst discerning between the relevant factors. In this regard several factors are simultaneously at play, for example the tradition, Scripture, the actual ritual practice, the surrounding cultures, etcetera, which all need to be taken into account in order to move towards a theory for praxis and an inculturated liturgy. In this regard firstly the (theological) concept of reconciliation will be revisited as used by liturgists, and secondly the concept of healing will be revisited as unpacked by a Ritual Studies scholar.

As mentioned in the previous section, reconciliation including restoration - was one of the two most central core codes that were found in the interviews. It has already been interpreted to an extent and will now be dealt with further. One definition of reconciliation is the following:

Reconciliation is the continuous process through ritual and justice aimed at the restoration of broken relationships, so that a new reality which is qualitatively different to any previous relationships come into being. (Wepener 2009:49)

If one were to adapt this definition slightly, mainly by interpreting it in terms of emotional healing, one would see that it's a process that happens over a longer period of time than the change that occurs in a rite of passage and also with regard to transformation. It is being constantly restored and constantly restoring. Another way to put it is that healing by means of restoration and reconciliation is something that, depending on the person, will need to be performed continuously from worship service to worship service.

The Hebrew word for peace is 'shalom', according to translators - the term in its biblical essence eludes more to a sense of completeness, wholeness, peace, health, welfare, safety, soundness and so forth. In other words 'shalom' speaks of holistic ('holy') health for one's soul and spirit. The reconciliation that is in question here is this state of shalom and this is something that is continually strived towards (cf. Wepener 2015c). A helpful way to understand healing as it relates to ritual practice is to distinguish it from curing.

When looking at healing rituals, 'medical sociologists' (cf. Grimes 2000) make a distinction between being healed and being cured. This is the result of them distinguishing illness from sickness:

Sickness is the biological reality; illness is the social reality. Sickness happens, but illness is socially imagined and constructed. Illness is what patients, families and doctors make of sickness; illness is how we frame and imagine sickness. Cancer is a sickness, but insofar as it is imagined as an 'enemy' whom we 'fight', it is also an illness. Healing rites deal more effectively with illness than with sickness. (p. 342)

This is what paves the road for the distinction between being healed and being cured. If someone is cured, their illness goes away and they are 'fixed'. On the other hand if someone is healed they are reconnected; one may or may not be cured but one will have a different attitude towards the illness. 'Rites heal more effectively than they cure' (Grimes 2000:342-343). Another quotation from Grimes (2000) is helpful in this regard:

Falling ill and being healed are not usually considered rites of passage, even though in some societies they are widely ritualized events. Healing rites are usually repetitious rather than onceand-for-all, like rites of passage are supposed to be. The other reason that healing rites are not considered rites of passage is that illness is not confined to a particular phase of human life. (p. 337)

This insight from Grimes is very helpful in this research. Grimes (2000) goes on and says:

However, studies of the human life course demonstrate that acute illness can become major spiritual passages. There is little doubt that chronic illness has ritualistic qualities about it - if nothing else, it is repetitious. But acute illness is literally life transforming in the way a rite of passage is said to be. A serious illness creates a 'before' and 'after' that differ markedly from each other. (p. 342)

In summation, healing can be as a result of a rite of passage or just a ritual. It is an effect of a rite of passage when the healing transformation is a one-off experience and is not needed again. Healing is also just a ritual in the way that even though there is a transformation it is not once-and-forall - it is repetitive. However, from a Christian perspective either explanation may still be seen as a rite of passage, something that moves one from one passage of life to another through transformation.

\section{Conclusion}

The worship service must allow for healing both by means of reconciliation and ritual action, and by means of transformation and rites of passage. At the time the research was conducted, the worship services, participated in, did allow for the above. The typical Methodist order of worship and its invitation into healing begins with 'The Preparation' and ends after 'The Intercessions' are complete (cf. Methodist Conference Office 1975:B19-B21). What will specifically allow for the Sunday Service to be a time and place of healing is the emphasis on the service not being specific. Of course, the sermon needs to be specific, but it need not affect the worship set. So, to simplify it further, the liturgy should be set up with the aim of being nonspecific. This implies an open invitation for the congregation to enter into worship and to experience and express exactly what their emotions, as a collective and as individuals, bring forth. Another way to put this is that after leaving the church many people will have gone to 
the same place and collectively they would have had the same experience. However, as individuals, on a personal and private level each person would have experienced something different from the person next to them and something unique. The Yale homiletician Nora Tisdale's (2008) work is helpful here, where she states that with regard to preaching, a preacher will do well to remember that all people are like all other people, no other people and some other people. From time to time all people are like all other people and need healing in their lives. This insight can serve as a first small but helpful step towards the pragmatic task for this study.

The Sunday service serves many different purposes and fulfils many different needs. In the same way that some people use water to drink, others to wash their clothes and others to water their crops. There are many purposes for the same thing. If the liturgy, from the first hymn to the last, is set up as an open invitation where each and every person can get emotionally invested in what is going on, then there will be a space where each person can truly fulfil their 'recurring needs' properly, whether it be healing, forgiveness or piece of mind. There is evidence of this in the already existing worship service. There are occasions when the above occurs in a worship service. The need now is to enhance the healing invitation so that it is available all the time to every worshipper and not only on a few occasions or to the minority of worshippers.

Another element to consider is that the 'healing' being discussed can be grouped into two different services: (1) nonspecific and (2) specific. The first group is where the worship service is an open worship service - there is no direct connotation to it being a healing service. The second group is when the worship service is specified as a 'healing service'. There is a time for the specific service, but not every Sunday can be specified - hence the need for the non-specific group, where the invitation is extended indirectly.

In essence and in conclusion, however, it became clear that worship services will do well if there is space for both one-off transformation experiences comparable to rites of passage as well as repetitive reconciliatory (restorative) experiences comparable to rituals seeing that both spaces will enhance the possibility of healing as either transformation or reconciliation to occur in and through the liturgy. This is also the core of the liturgical theory for praxis this article wishes to contribute to the on-going discussion related to healing and worship in Africa in line with Grimes' (2000:343) helpful distinction, namely 'to be cured is to be fixed, but to be healed is to be - reconnected'.

\section{Acknowledgements Competing interests}

The authors declare that they have no financial or personal relationships which may have inappropriately influenced them in writing this article.

\section{Authors' contributions}

The article is based on H.S.'s master's dissertation and C.J.W. was the supervisor.

\section{References}

Babbie, E. \& Mouton, J., 2001, The practice of social research, Oxford University Press Southern Africa, Cape Town.

Barnard, M., Cilliers, J.H. \& Wepener, C.J., 2014, Worship in the network culture. Liturgical ritual studies. Fields and methods, concepts and metaphors, Liturgia Condenda 28, Peeters, Leuven.

Bell, C., 1997, Ritual: Perspectives and dimensions, Oxford University Press, New York.

Chupungco, A.J., 1992, Liturgical inculturation: Sacramentals, religiosity, and catechesis, The Liturgical Press, Collegeville, MN.

De Gruchy, J., 2001, Reconciliation. Restoring justice, David Philip, Cape Town.

Geertz, C., 1973, The interpretation of cultures, Basic Books, New York.

Grimes, R.L., 2000, Deeply into the bone: Re-inventing rites of passage, University of California Press, Berkeley, CA.

Hay, M., 1997, 'Ukubuyisana. Reconciliation in South Africa', PhD thesis, Catholic Theological Union of Chicago.

Lukken, G., 1997, 'Liturgiewetenschappelijkonderzoek in culturele context. Metodischeverheldering en vragen', Jaarboekvoorliturgie-onderzoek 13, 135-148. Lukken, G., 1999, Rituelen in overvloed, Gooi \& Sticht, Baarn.

Methodist Conference Office, 1975, The methodist service book, The Garden City Press Limited.

Muchimba, F., 2007, Liberating the African soul: Comparing African and Western Christian Music and worship styles, Authentic Publishing, Colorado Springs, CO.

Osmer, R.R., 2008, Practical theology: An introduction, Eerdmans, Grand Rapids, MI.

Pieterse, H.J.C., 2010, 'Grounded theory approach in sermon analysis of sermons on poverty and directed at the poor as listeners', Acta Theologica 30(2), 113-129.

Pieterse, H.J.C., 2012, 'A grounded theory approach to the analysis of sermons on poverty: Congregational projects as social capital', Verbum et Ecclesia 33(1), 1-7.

Pieterse, H.J.C., 2013a, 'An emerging grounded theory for preaching on poverty in South Africa with Matthew 25:31-46 as sermon text', Acta Theologica 33(1), 175-195.

Pieterse, H.J.C., 2013b, 'Theoretical strengthening of the concept of appealing in analysed sermons on Matthew 25:31-46 in the context of poverty in South Africa', In die Skriflig/In Luce Verbi 47(1), 1-8. https://doi.org/10.4102/ids.v47i1.692

Post, P.G.J., 2014, 'Genezing vindt plaats. Tussenruimte', Tijdschrift voor interculturele theologie 7(1), 46-51.

Root, A., 2014, Christopraxis. A practical theology of the cross, Fortress Press, Minneapolis, MN

Scott, H.R., 2013, 'Healing and transformation through the worship service: A ritualliturgical exploration', masters dissertation, University of Pretoria.

Strydom, H., 2002, 'Participatory action research', in A.S. de Vos et al. (ed.), Research at grass roots. For the social sciences and human service professions, pp. 408-423, Van Schaik, Pretoria.

Thumma, S.L., 1998, 'Methods for congregational study', in N.T. Ammerman, J.W. Carroll, C.S. Dudley \& W. McKinney (eds.), Studying congregations: A new handbook, pp. 196-239, Abingdon Press, Nashville, TN.

Tisdale, L.T., 2008, 'Exegeting the congregation', in T.G. Long \& L.T. Tisdale (eds.), Teaching preaching as a christian practice. A new approach to homiletical pedagogy, pp. 75-89, WJK, Louisville, KY.

Turner, V.W., 1969, The ritual process. Structure and anti-structure, Routledge \& Kegan Paul, London.

Van Gennep, A., 1960, The rites of passage, University of Chicago Press, Chicago, IL.

Wepener, C.J., 2005, 'Researching rituals. On the use of participatory action research in liturgical studies', PraktieseTeologie in Suid-Afrika 20(1), 109-127.

Wepener, C.J., 2008, 'Liturgy on the edge of tradition', Practical Theology in South Africa 23(2), 313-335.

Wepener, C.J., 2009, From fast to feast: A ritual-liturgical exploration of reconciliation in South African cultural contexts, Peeters, Dudley, MA.

Wepener, C.J., 2010, 'Liturgical research in a changing South African socio-cultural (liturgical) landscape: Challenges and opportunities for method and theory', in I. Swart, H. Rocher, S. Green \& J. Erasmus (eds.), Religion and social development in post-apartheid South Africa: Perspectives for critical engagement, pp. 403-415, post-apartheid South Africa.
SUN Press, Stellenbosch.

Wepener, C.J., 2012a, 'Reflections on recent developments in liturgical studies in the light of experiences from the research field and the lecture room', Journal of Theology for South Africa 144, 109-125.

Wepener, C.J., 2012b, 'Ritual route markers for reconciliation: Insights from a South African exploration', Theologia Viatorum 36(2), 291-310.

Wepener, C.J., 2013, 'Liturgical "reform" in Sub-Saharan Africa: Some observations on worship, language and culture', Studia Liturgica 44(1-2), 82-95.

Wepener, C.J., 2014, 'La "réforme" liturgique en Afrique sub-saharienne: Observations sur le culte, la langue et la culture', La Maison-Dieu 278(2), 123-145. 
Wepener, C.J., 2015a, 'Burning incense for a focus group discussion. A spirituality of liminality for doing liturgical research in an African context from an emic doi.org/10.1515/ijpt-2014-0036

Wepener, C.J., 2015b, Boiling point! A faithful reaction of a disillusioned nation. Reflections on anger, Biblecor, Wellington.

Wepener, C.J., 2015c, 'African therapy for a fractured world (view): The life of founder bishop Johannes Richmond and the invention of tradition and group cohesion in an African Initiated Church', HTS Teologiese Studies/Theological Studies 71(1), 1-9. https://doi.org/10.4102/hts.v71i1.2900
Wepener, C.J. \& Barnard, M., 2010, 'Entering the field: Initiating liturgical research in an AIC', Acta Theologica 30(2), 192-210.

Wepener, C.J. \& Müller, B.A., 2013, 'Water rituals as a source of (Christian) life in an African Independent Church: To be healed and (re)connected', Nederduitse Gereformeerde Teologiese Tydskrif 54(1\&2), viewed 01 August 2015, from http:// ngtt.journals.ac.za/pub/article/view/316/423

Wepener, C.J. \& Pieterse, H.J.C., 2016, 'Angry preaching. A grounded theory analysis of sermons of anger', paper delivered at the Societas Homiletica, Stellenbosch University. 